Billikopf responds to these concerns in an article on pre-caucusing published in the journal Group Facilitation (Spring 2002). He also incorporated information on pre-caucusing into the second edition of his book, Labor Management in Agriculture: Cultivating Personnel Productivity, published by the UC Agricultural Issues Center in English and Spanish in mid-2003.

Pre-caucusing is slowly being adopted not only in agriculture and the workplace, but also in other settings where mediators solve interpersonal conflicts such as women's shelters, churches and community mediation centers, as well as by attorneys and professors of conflict management and organizational behavior.

"It also helps facilitators understand factors that affect the likelihood of success," Billikopf says, "so a more informed decision can be made as to whether to bring both parties into a joint session."

Billikopf says his experiences in recent years with pre-caucusing have caused him to reevaluate his initial forays into mediating labor disputes, where he had not sufficiently understood the potential of the pre-caucus. "I wish I knew then, what I know now."

For more information, go to: www.cnr.berkeley.edu/ ucce50/ag-labor/.

\title{
Rural youth report more frequent smoking and drinking
}

$\mathrm{R}$ ural youth report high-risk behaviors such as smoking and drinking alcohol more frequently than their urban counterparts, according to a January report from the UC 4-H Center for Youth Development at UC Davis.

The report, "California's Rural Youth," found that California rural adolescents aged 12 to 17 are nearly four times as likely to smoke cigarettes frequently, and are significantly more likely to drink alcohol.

"The higher rates of smoking among rural youth are of great concern," says lead author Katherine Heck, UC Davis associate specialist.

"In the future, many of these young people will face health problems because of smoking. We found that about $8 \%$ of rural adolescents smoked cigarettes regularly, and more than half of them began smoking before age 13." (See page 28 for research on how California's Proposition 10 "tobacco tax" funds are distributed.)

Heck and her colleagues also found that significantly more rural youths $(39 \%)$ than urban youths $(29 \%)$ have drunk alcohol. More than one in four $(26 \%)$ rural California adolescents has ridden with a driver who had been drinking alcohol, compared with $17 \%$ of urban youth.

"Rural areas often lack public forms of transportation that might be available in urban areas, so drinking and driving may be a greater problem for rural youth," Heck says.

The UC researchers also found that about $14 \%$ of
California's rural youth had no health insurance in 2001, compared with $11 \%$ of adolescents statewide. Those rural youth who did have insurance were more likely to be insured through public programs such as Medi-Cal or Healthy Families. Fewer than half of rural adolescents had employersponsored health insurance.

Despite certain challenges, however, rural adolescents

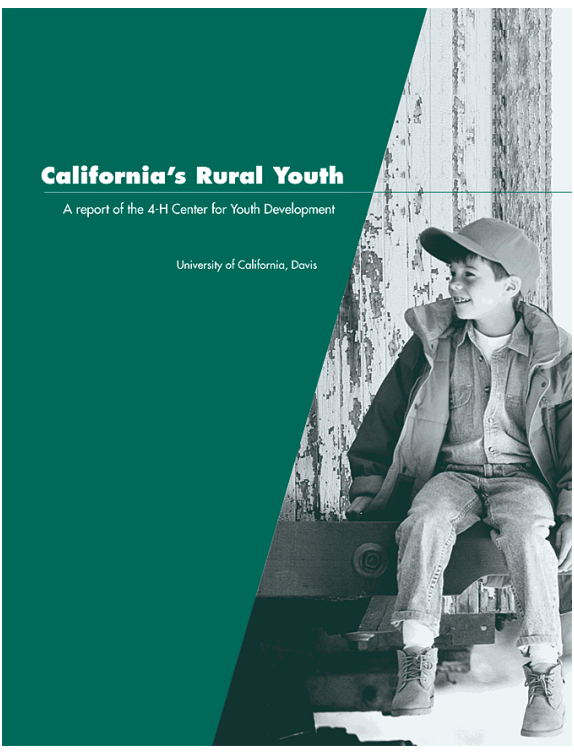
have bright futures, says Stephen Russell, director of the UC 4-H Center for Youth Development. "Most rural youth, 79\%, said there was a purpose to their lives, and $82 \%$ reported having goals and plans for the future."

Russell notes that $65 \%$ of rural youth reported they have an adult at home who talks with them about their problems, and $77 \%$ have an adult at home who listens when they have something to say.

The report was compiled by a team of researchers and UCCE youth development professionals and draws from multiple sources of state and local data, including the California Health Interview Survey, the California Healthy Kids Survey and the National Longitudinal Study of Adolescent Health.

For more info., go to: http://fourhcyd.ucdavis.edu. - Editors 